\title{
Peran Penerapan Model Problem Based Learning (PBL) terhadap Kemampuan Literasi Matematis dan Kemandirian Belajar
}

\author{
Rahmat Hidayat ${ }^{1}$, Yenita Roza ${ }^{2}$, dan Atma Murni ${ }^{3}$ \\ ${ }^{1.2 .3}$ Program Pascasarjanastudi pendidikan matematika, Universitas Riau \\ e-mail: rahmat.hidayat@grad.unri.ac.id
}

\begin{abstract}
This article is based on the low ability of mathematical literacy and learning independence of learners. This article aims to describe the role of the PBL model of mathematical literacy and learning independence. The type of research used in this article is quantitative descriptive research conducted on students of class VIII MTs Darul Wasi'ah Simalinyang through interviews with learners and teachers, observation, and literature review analyzed descriptively.
\end{abstract}

Keywords: Mathematical Literacy, Learning Independence, PBL.

\begin{abstract}
ABSTRAK. Artikel ini dilatar belakangi oleh rendahnya kemampuan literasi matematis dan kemandirian belajar peserta didik. Artikel ini bertujuan untuk mendeskripsikan peran model PBL terhadap kemampuan literasi matematis dan kemandirian belajar. Jenis penelitian yang digunakan pada artikel ini adalah penelitian deskriptif kuantitatif yang dilakukan pada peserta didik kelas VIII MTs Darul Wasi'ah Simalinyang melalui wawancara dengan peserta didik dan guru, observasi, dan kajian literatur yang dianalisis secara deskriptif.
\end{abstract}

Kata kunci: Literasi Matematis, Kemandirian Belajar, PBL.

\section{PENDAHULUAN}

Perkembangan teknologi yang sangat pesat pada abad 21 ini tidak lepas dari perkembangan ilmu pengetahuan salah satunya adalah matematika. Matematika merupakan ilmu universal yang mendasari perkembangan teknologi modern serta mempunyai peran yang sangat penting dalam berbagai disiplin ilmu dalam mengembangkan daya pikir manusia. Pentingnya matematika dalam kehidupan sehari-hari mengharuskan setiap orang untuk mempelajari matematika. Matematika sebagai bidang ilmu perlu diajarkan kepada peserta didik karena (1) selalu digunakan dalam segala segi kehidupan, (2) semua bidang studi memerlukan keterampilan matematika yang sesuai, (3) merupakan sarana komunikasi yang kuat, singkat dan padat, (4) dapat digunakan untuk menyajikan informasi dalam berbagai cara, (5) meningkatkan kemampuan berpikir logis, ketelitian dan kesadaran keruangan, dan (6) memberikan kepuasan terhadap usaha memecahkan masalah yang (Cokroft, 2003).

Salah satu tujuan pembelajaran matematika yang terdapat dalam lampiran Permendikbud No.58 Tahun 2014 tentang kurikulum SMP mata pelajaran matematika adalah menggunakan pola sebagai dugaan dalam penyelesaian masalah, dan mampu membuat generalisasi berdasarkan fenomena atau data yang ada, serta menggunakan penalaran pada sifat, melakukan manipulasi matematika baik dalam penyederhanaan, maupun menganalisis komponen yang ada dalam pemecahan masalah dalam konteks matematika maupun diluar matematika (kehidupan nyata, ilmu, dan teknologi) yang meliputi kemampuan memahami masalah, membangun model matematika, menyelesaikan model dan menafsirkan solusi yang diperoleh termasuk dalam rangka memecahkan masalah dalam kehidupan sehari-hari (Kemendikbud, 2014).

Apabila dicermati, kemampuan memahami masalah, membangun model matematika, menyelsaikan model, menafsirkan, dan memecahkan masalah tersebut mengacu pada definisi 
literasi matematis, karena literasi matematika merupakan kapasitas individu untuk merumuskan, menggunakan dan menafsirkan matematika. Merumuskan melibatkan mengenali dan mengidentifikasi peluang untuk menggunakan matematika, memberikan struktur matematika pada masalah yang disajikan dalam beberapa bentuk kontekstual. Penggunaan konsep, fakta, prosedur, dan penalaran matematis untuk memecahkan masalah yang diformulasikan secara matematis dan untuk mendapatkan kesimpulan matematis. Selanjutnya, untuk menafsirkan matematika melibatkan pemantapan solusi, hasil, atau kesimpulan matematis dan menafsirkannya dalam konteks dunia nyata(Hara, F, O,., Bolstad, O, H., \& Jenssen, E, 2017). Literasi matematika merupakan pengetahuan untuk mengetahui dan menerapkan matematika dasar dalam kehidupan sehari-hari (Ojose, 2011).

Namun pentingnya kemampuan literasi matematis untuk mencapai kemampuan pemecahan masalah tidak sesuai dengan fakta yang ada Hal ini dapat dilihat dalam laporan studi PISA tahun 2015. Rangking Indonesia untuk Sains (62), Matematika (63), dan Membaca (64) dari 70 negara. Rata-rata skor peserta didik Indonesia untuk kemampuan literasi matematis adalah 375 (level 1) sedangkan rata-rata skor internasional adalah 500 (level 3). Level 1 adalah level terendah dari 6 level kemampuan literasi matematis yang diterapkan PISA(OECD, 2016).

Selain fakta diatas, hasil wawancara peneliti dengan guru bidang studi matematika di SMP, juga menunjukkan hal yang tidak jauh berbeda.Peserta didik masih mengalami kesulitan dalam memahami permasalahan dalam soal-soal kontekstual yang diberikan.Hal ini dapat dilihat dari penyelesaian soal kontektual yang dijawab oleh peserta didik.Peserta didik mengalami kesulitan dalam menentukan permasalahan yang ditanyakan di soal yang diberikan.

Fakta lain yang menunjukkan lemahnya kemampuan pemecahan masalah adalah hasil tes yang dilakukan di sekolah tempat peneliti bertugas. Peserta didik masih mengalami kesulitan dalam memecahkan masalah pada bab SPLDV. Jawaban peserta didik dapat dilihat pada Gambar 1.

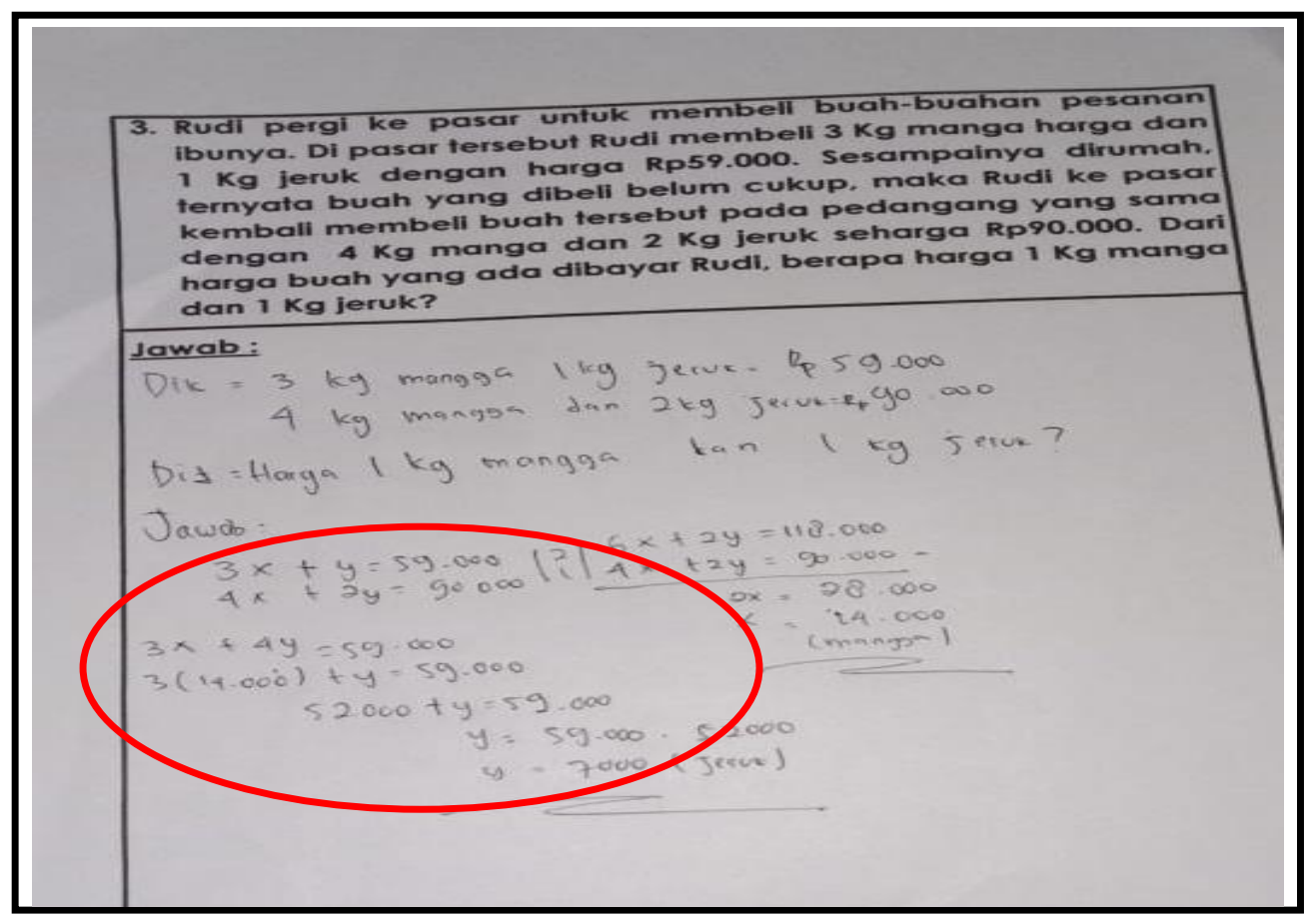

Gambar 1. Jawaban peserta didik

Jawaban tersebut memperlihatkan bahwa peserta didik sudah mampu mengkonstruksi permasalahan, dimana peserta didik sudah dapat mengetahui apa yang ditanyakan dan apa saja yang diketahui dari permasalahan tersebut. Namun peserta didik terlihat melakukan kesalahan dalam proses penyelesaian soal. Pada lingkaran merah yang dibuat, peserta didik melakukan kesalahan pengoperasian dalam memecahkan masalah tersebut.Peserta didik mengalikan 3 dengan 
niai $x$ menghasilkan 52.000 harusnya adalah 42.000. Kesalahan kecil seperti ini sering dilakukan oleh peserta didik, sehingga berimbas pada hasil belajar dan sikap peserta didik yang kurang teliti.

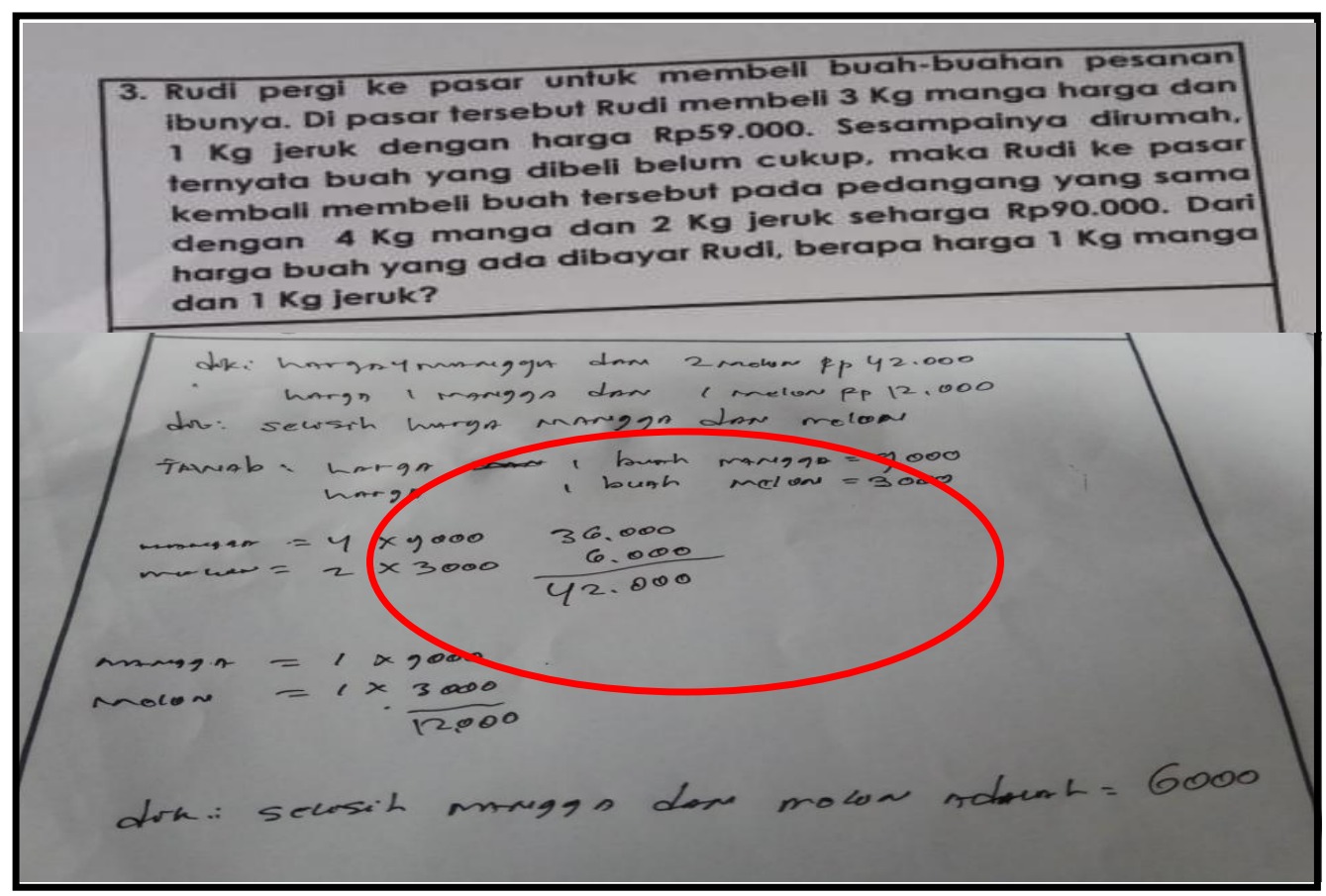

Gambar 2. Jawaban Peserta didik

Jawaban di atas sudah memperlihatkan kemampuan peserta didik dalam memahami apa yang diketahui dari permasalahan tersebut dan apa yang menjadi pertanyaan, namun peserta didik belum mampu merubah bentuk persoalan menjadi kalimat matematika. Jawaban peserta didik didapat bukan melalui proses, namun lebih mengarah dengan cara mensubstitusi bilangan-bilangan yang mungkin untuk membuat kalimat tersebut menjadi benar.

Untuk mencapai literasi matematis, maka harus ada kemampuan yang menunjang pencapaian tujuan dari literasi tersebut. Kemampuan yang dapat menunjang untuk tercapainya tujuan literasi adalah kemandirian belajar. Kemandirian dalam belajar mengacu pada pembelajaran yang terjadi terutama dari pengaruh pemikiran, perasaan, strategi, dan perilaku yang dihasilkan oleh peserta didik, yang berorientasi pada pencapaian tujuan. Kemandirian belajar digambarkan sebagai individu yang secara aktif terlibat dalam lingkungan belajar, mengatur, melatih, dan menggunakan kemampuannya secara efektif, dan memiliki keyakinan motivasi yang positif tentang kemampuannya dalam pembelajaran(Iwamoto, D, H., Hargis, J., Bordner, R., \& Chandler, 2017). Ada tiga tahap utama siklus kemandirian belajar. Tahap pertama adalah perencanaan belajar. Pada tahap ini peserta didik menetapkan tujuan pembelajaran, mengaktifkan pengetahuan, dan rencana awal tentang bagaimana mencapai tujuan pembelajaran. Tahap keduan adalah kinerja. Selama tahap ini, peserta didik memantau kemajuan saat menerapkan rencana dengan menyadari kognisi, motivasi, dan perilaku. Tahap ketiga adalah refleksi diri. Di sini peserta didik mengevaluasi kinerja dan menentukan apa yang berhasil dan apa yang dapat ditingkatkan agar proses belajar lebih baik (Iwamoto, D, H., Hargis, J., Bordner, R., \& Chandler, 2017).

Kemandirian belajar merupakan salah satu hal yang penting dalam suatu proses pembelajaran. Karena kemandirian belajar dapat melatih peserta didik untuk tidak bergantung pada orang lain. Selain itu kemandirian yang dimiliki peserta didik juga dapat menumbuhkan kepercayaan diri. Salah satu hambatan dalam pendidikan adalah rendahnya rasa kemandirian belajar peserta didik, sehingga dengan adanya hambatan tersebut akan mengakibatkan rendahnya mutu pendidikan.

Dalam artikel ini, peneliti menggunakan model pembelajaran PBL agar dapat membantu peserta didik dalam mencapai tujuan literasi matematis dan kemandirian belajar. Dalam model 
PBL, peserta didik dibimbing mengikuti langkah-langkah pemecahan masalah secara sistematis sehingga memberikan dampak terhadap kemampuan pemecahan masalah matematis. Adapun langkah-langkah yang dimaksud yaitu: 1) kegiatan memahami masalah; 2) kegiatan merencanakan atau merancang strategi pemecahan masalah; 3) kegiatan melaksanakan perhitungan 4) kegiatan memeriksa kembali kebenaran hasil atau solusinya. Peserta didik didorong menyelesaikan masalah secara sistematis sehingga peserta didik terlatih untuk menyelesaikan permasalahan matematika yang tidak rutin (Polya, 1985). Gambaran permasalahan tersebut menunjukkan bahwa begitu pentingnya kemampuan literasi dan kemandirian belajar dalam pembelajaran matematika. Tujuan artikel ini adalah mendeskripsikan kualitas model pembelajaran PBL terhadap kemampuan literasi matematika dan kemandirian belajar peserta didik, dan menganalisis kemampuan literasi matematis dan kemandirian belajar peserta didik melalui model pembelajaran PBL

\section{METODE}

Metodologi yang digunakan adalah penelitian deskriptif kuantitatif, karena dalam penelitian ini mendeskripsikan peran PBL terhadap kemampuan literasi matematis dan kemandirian belajar. Penelitain deskriptif adalah penelitian yang dimaksudkan untuk menyelidiki keadaan, kondisi, atau hal-hal lain yang sudah disebutkan, yang hasilnya dipaparkan dalam bentuk laporan penelitian.Penelitian ini tidak mengubah, menambah, atau mengadakan manipulasi terhadap objek atauwilayah penelitian. Peneliti hanya memotret apa yang terjadi pada diriobjek atau wilayah yang diteliti, kemudian memaparkan apa yang terjadidalam bentuk laporan penelitian secara lugas, seperti apa adanya (Arikunto, 2010). Penelitian ini termasuk dalam penelitian kuantitatif. Metode kuantitatif, yaitu sebuah metode penelitian yang bertujuanmenggambarkan fenomena atau gejala sosial secara kuantitatif ataumenjelaskan bagaimana fenomena atau gejala sosial yang terjadi dimasyarakat saling berhubungan satu sama lain (Martono, 2015)Metode deskriptif kuantitatif dalam penelitian ini adalah metode yangdigunakan dalam menyelesaikan suatu penelitian ilmiah dengan tujuan untuk memecahkkan masalah yang sedang diteliti yaitu tentang peran model PBL terhadap kemampuan literasi matematis dan kemandirian belajar.

\section{HASIL DAN PEMBAHASAN}

Berdasarkan hasil observasi dan wawancara yang dilakukan peneliti terhadap guru dan peserta didik kelas VIII MTs Darul Wasi'ah Simalinyang diperoleh informasi bahwa kemampuan literasi matematis peserta didik masih rendah.Hal ini dapat dilihat dari sulitnya peserta didik dalam menyelesaikan soal-soal kontekstual, dan kecendrungan peserta didik menyukai soal-soal rutin.Ini sejalan dengan penelitian yang dilakukan oleh Rahmawati dan Mahdiansyahyang mengatakan bahwa kemampuan literasimatematika peserta didik Indonesia masih rendah.Selain itu hasil penelitian yangdilakukan PISA pada tahun 2000, 2003, 2006, 2009, 2012, dan 2015. Indonesia selalumasuk dalam 10 negara dengan kemampuan literasi matematika yang rendah(Rahmawati dan Mahdiansyah, 2014).

Pada penelitian yang dilakukan oleh Nur Indah, dkk juga menunjukkan hal yang sama, bahwa kemampuan literasi matematis peserta didik masih rendah. Hal ini ditunjukkan dari ketidakmampuan siswa dalam menyelesaikan masalah yang bentuknya merumuskan, menerapkan, bahkan menafsirkan matematika ke dalam berbagai konteks(Indah, Mania, \& Nursalam, 2016). Rendahnya kemampuan literasi matematis peserta didik akan mempengaruhi kemampuan peserta didik dalam memahami pembelajaran matematika secara keseluruhan. Peserta didik akan kesulitan menyelesaikan permasalahan matematika berbentuk soal-soal kontekstual. Soal-soal kontekstual merupakan soal-soal yang mengajarkan peserta didik dalam menyelesaikan setiap permasalahan sehari-hari. Ketika seseorang sulit dalam menyelesaikan permasalahan yang ada dalam kehidupan sehari-hari, maka orang tersebut akan kesulitan pula dalam bersaing di era globalisasi ini.

Dari penjelasan di atas, kemampuan literasi matematis sudah sewajarnya menjadi hal yang harus ditingkatkan demi meningkatnya kemampuan memecahkan permasalahan matematika yang ada di kehidupan sehari-hari. Namun tujuan pembelajaran matematika tidak akan tercapai dengan 
baik jika hanya ada satu faktor penunjang keberhasilan belajar yakni kemampuan literasi matematis saja, faktor lain yang dapat mempengaruhi kualitas belajar peserta didik sehingga tujuan pembelajaran tercapai adalah kemandirian belajar. Kemandirian merupakan salah satu unsur kepribadian penting, karena diperlukan manusia untuk menyesuaikan diri secara aktif dalam lingkungannya.Selain kemampuan literasi matematis, kemandirian belajar juga akanmempengaruhi kemampuan peserta didik dalam menyelesaikan masalah. Kemandirian belajar digambarkan sebagai individu yang secara aktif terlibat dalam lingkungan belajar, mengatur, melatih, dan menggunakan kemampuannya secara efektif, dan memiliki keyakinan motivasi yang positif tentang kemampuannya dalam pembelajaran (Iwamoto, D, H., Hargis, J., Bordner, R., \& Chandler, 2017).

Kemandirian belajar merupakan salah satu hal yang penting dalam suatu proses pembelajaran. Karena kemandirian belajar dapat melatih peserta didik agar tidak tergantung dengan orang lain. Selain itu kemandirian yang dimiliki peserta didik juga dapat menumbuhkan kepercayaan diri. Salah satu hambatan dalam pendidikan adalah rendahnya rasa kemandirian belajar peserta didik, sehingga dengan adanya hambatan tersebut akan mengakibatkan rendahnya mutu pendidikan.

Hal yang dapat dilakukan untuk mengatasi rendahnya kemampuan literasi dan kurangnya kemandirian belajar peserta didik adalah dengan memilih dan menerapkan model pembelajaran yang mampu merangsang peserta didik untuk meningkatkan kemampuan literasi dan meningkatkan kemandirian belajar dalam memahami pelajaran matematika. Dari model pembelajaran yang ada, model pembelajaran yang dapat meningkatkan kemampuan literasi matematis dan kemandirian belajar adalah model pembelajaran Problem Based Learning (PBL), karena model PBL merupakan inovasi dalam pembelajaran, hal ini karena dalam PBL kemampuan berpikir peserta didik betul-betul dioptimalisasikan melalui proses kerja kelompok atau tim yang sistematis, sehingga peserta didik dapat memberdayakan, mengasah, menguji, dan mengembangkan kemampuan berfikirnya secara berkesinambungan (Tan, 2009).

Dalam model PBL, peserta didik dibimbing mengikuti langkah-langkah pemecahan masalah secara sistematis sehingga memberikan dampak terhadap kemampuan pemecahan masalah matematis. Adapun langkah-langkah yang dimaksud yaitu: 1) kegiatan memahami masalah; 2) kegiatan merencanakan atau merancang strategi pemecahan masalah; 3) kegiatan melaksanakan perhitungan 4) kegiatan memeriksa kembali kebenaran hasil atau solusinya. Peserta didik didorong menyelesaikan masalah secara sistematis sehingga peserta didik terlatih untuk menyelesaikan permasalahan matematika yang tidak rutin (Polya, 1985). Pembelajaran Matematika hendaknya dimulai dengan pengenalan masalah atau mengajukan masalah riil atau nyata, yaitu pembelajaran yang mengaitkan dengan kehidupan sehari-hari peserta didik, kemudian peserta didik secara bertahap dibimbing untuk menguasai konsep Matematika dengan melibatkan peran aktif peserta didik dalam proses pembelajaran. Ketika peserta didik belajar matematika, maka yang dipelajari adalah penerapan matematika yang dekat dengan kehidupan peserta didik.Situasi pembelajaran sebaiknya dapat menyajikan fenomena dunia nyata, masalah yang autentik dan bermakna, dapat menantang peserta didik untuk memecahkannya. Guru harus dapat membuka wawasan berpikir yang beragam dari seluruh peserta didik, sehingga dapat mempelajari berbagai konsep dan cara mengaitkannya dalam kehidupan nyata. Guru yang baik dan bijaksana mampu menggunakan model pembelajaran yang berkaitan dengan cara memecahkan masalah (problem solving). Salah satu model pembelajaran yang diterapkan adalah pengajaran berdasarkan masalah atau Problem Based Learning (PBL) (Hery, 2017).

\section{REFERENSI}

Abidin, Y. (2014). Desain Sistem Pembelajaran. Bandung: PT. Refika Aditama.

Arikunto, S. (2010). Prosedur Penelitian Suatu Pendekatan Praktik. Jakarta: Rineka Cipta.

Cokroft, W. . (2003). Mathematics Counts, Report of the Committee of Inguiri Into the Teaching of Mathematics in School. London: Her Majesty's Stationery Office.

Dadan, R. (2016). Penerapan Model Problem Based Learning (PBL) dalam Upaya Meningkatkan Kemampuan Berpikir Kreatif Dan Keaktifan Belajar Peserta didik SMP (Tesis). Universitas Pasundan. 
Delisle, R. (1997). How to Use Problem Based Learning in The Classroom. Alexandria, USA: Assotiation for Supervision and Curriculum Development.

Dewey, J. (2010). Strategi Pembelajaran Berbasis Masalah. Artikel Pendidikan. Edukasiana. Retrieved from http://edukasiana.com/?p=266

Fanihu. (2013). Meningkatkan Kemampuan Berfikir Kritis dan Kemandirian belajar Matematika pada Mahasiswa melalui Pembelajaran Generatif. UPI.

Fitriana, S., Ihsan, H., \& Annas, S. (2015). Pengaruh Efikasi Diri, Aktifitas, Kemandirian Belajar, dan Kemampuan Berfikir Logis terhadap Hasil Belajar Matematika pada Peserta didik Kelas VII SMP. Journal of EST, 1(2).

Hara, F, O,., Bolstad, O, H., \& Jenssen, E, S. (2017). Research on Mathematical Literacy in School-Aim, Approach and Attantion. European Journal Od Science and Mathematical Education, $5,3$.

Hery, S. (2017). Pembelajaran Matematika Model PBL (Problem Based Learning) Pada Mata Pelajaran Matematika Materi Luas Bidang Pada Peserta didik Kelas III SD. Jurnal INOV ASI, Volume XIX.

Indah, N., Mania, S., \& Nursalam. (2016). Peningkatan Kemampuan Literasi Matematika Siswa Melalui Penerapan Model Pembelajaran Problem Based Learning di Kelas VII SMP Negeri 5 Pallangga Kabupaten Gowa. Jumal Matematika Dan Pembelajaran, 4(2), 200-210. https://doi.org/https://doi.org/10.24252/mapan.2016v4n2a4

Iwamoto, D, H., Hargis, J., Bordner, R., \& Chandler, P. (2017). Self-Regulated Learning as a Critical Attribute for Successful Teaching and Learning. Nternational Journal for the Scholarship of Teaching and Learning, 2, 11.

Kemendikbud. Permendikbud Nomor 81A tahun 2013 Tentang Implementasi Kurikulum (2013). Jakarta.

Kemendikbud. Peraturan Menteri Pendidikan dan Kebudayaan Nomor 58 Tahun 2014 tentang Kerangka Dasar dan Struktur Kurikulum Sekolah Menengah Pertama/Madrasah Tsanawiyah, Pub. L. No. Permendikbud (2014). Jakarta.

Kemendiknas. Pembinaan Pendidikan Karakter di Sekolah Menengah Pertama (2017). Jakarta.

Martinis, Y. (2013). Strategi dan Metode dalam Metode Pembelajaran. Jakarta: Gaung Persada Press.

Martono, N. (2015). Metode Penelitian Sosial. Jakarta: PT. RajaGrafindo Persada.

OECD. (2012). PISA 2009 Technical Report.

OECD. (2016). PISA 2015 Result in Focus. New York.

Ojose. (2011). Mathematics Literacy: Are We Able To Put The Mathematics We Learn Into Everday Use? Journal on Mathematic Education, 7, 1-8.

Oktaningrum, W., Zulkardi., \& Hartono, Y. (2016). Developing PISA-Like Mathematics Task with Indonesia Natural and Cultural Heritage As Context To Assess STUDENTS' Mathematical Literacy. Journal on Mathematic Education, 7 (1), 1-8.

Polya, G. (1985). How to Solve It. United States of America: Princeton University Press.

Rachmayani, D. (2014). Penerapan Pembelajaran Reciprocal Teaching untuk Meningkatkan Kemampuan Komunikasi Matematis dan Kemandirian Belajar Matematika Peserta didik. Jurnal Pendidikan Unsiska, Volume $2 \mathrm{~N}$.

Rahmawati dan Mahdiansyah. (2014). Mathematical Literacy Of Students At Secondary Education Level: An Analysis Using International Test Design with Indonesian Context. Jurnal Pendidikan Dan Kebudayaan, 4, 452-469.

Sari, R. H. (2015). Literasi Matematika: Apa, Mengapa, dan Bagaimana. Prossiding Seminar Nasional Matematika Dan Pendidikan Matematika. UNY. Yogyakarta.

Tan, O. . (2009). Problem Based-Learning Innovation: Using problems to Power Learning in tje 21st. Singapore: Cengage Learning Asia Pte. Ltd.

Torp, Linda dan Sage, S. (2002). Problem as Possibilities, Problem Based Learning for K-16. USA: Assotiation for Supervision and Curriculum Development. 